University of Nebraska - Lincoln

DigitalCommons@University of Nebraska - Lincoln

Publications, Agencies and Staff of the U.S.

Department of Commerce

U.S. Department of Commerce

4-2009

\title{
Record of Feeding by Humpback Whales (Megaptera novaeangliae) in Tropical Waters off Brazil
}

Luiz Claudio Pinto de sa Alves

Projeto Monitoramento de Baleias por Sat'elite, Instituto Aqualie, Rua Edgard Werneck, 428/32, Rio de Janeiro, RJ, 22763-010, Brazil

Artur Andriolo

Projeto Monitoramento de Baleias por Sat'elite, Instituto Aqualie, Rua Edgard Werneck, 428/32, Rio de Janeiro, RJ, 22763-010, Brazil

Alexandra Zerbini

Alaska Fisheries Science Center, NOAA Fisheries

Jose Luis Altmayer Pizzorno

Instituto Aqualie, Rua Edgard Werneck, 428/32, Rio de Janeiro, RJ, 22763-010, Brazil

Phillip Clapham

Alaska Fisheries Science Center, NOAA Fisheries

Follow this and additional works at: https://digitalcommons.unl.edu/usdeptcommercepub

Part of the Environmental Sciences Commons

Pinto de sa Alves, Luiz Claudio; Andriolo, Artur; Zerbini, Alexandra; Altmayer Pizzorno, Jose Luis; and Clapham, Phillip, "Record of Feeding by Humpback Whales (Megaptera novaeangliae) in Tropical Waters off Brazil" (2009). Publications, Agencies and Staff of the U.S. Department of Commerce. 45.

https://digitalcommons.unl.edu/usdeptcommercepub/45

This Article is brought to you for free and open access by the U.S. Department of Commerce at DigitalCommons@University of Nebraska - Lincoln. It has been accepted for inclusion in Publications, Agencies and Staff of the U.S. Department of Commerce by an authorized administrator of DigitalCommons@University of Nebraska - Lincoln. 
MARINE MAMMAL SCIENCE, 25(2): 416-419 (April 2009)

(C) 2009 by the Society for Marine Mammalogy

DOI: $10.1111 / j .1748-7692.2008 .00249 . x$

This article is a U.S. government work, and is not subject to copyright in the United States.

Record of feeding by humpback whales (Megaptera novaeangliae)

in tropical waters off Brazil

Luiz Cláudio Pinto de SÁ Alves

Projeto Monitoramento de Baleias por Satélite, Instituto Aqualie, Rua Edgard Werneck, 428/32,

Rio de Janeiro, RJ, 22763-010, Brazil

E-mail: lcpsalves@yahoo.com.br

\section{ARTUR ANDRiolo}

Projeto Monitoramento de Baleias por Satélite,

Instituto Aqualie, Rua Edgard Werneck, 428/32,

Rio de Janeiro, RJ, 22763-010, Brazil

and

Departamento de Zoologia,

Instituto de Ciências Biológicas,

Universidade Federal de Juiz de Fora, Campus Universitário,

Juiz de Fora, MG, 36036-330, Brazil

\section{Alexandre N. Zerbini}

Projeto Monitoramento de Baleias por Satélite,

Instituto Aqualie, Rua Edgard Werneck, 428/32,

Rio de Janeiro, RJ, 22763-010, Brazil and

National Marine Mammal Laboratory,

Alaska Fisheries Science Center, NOAA Fisheries, 7600 Sand Point Way NE,

Seattle, Washington 98115-6349, U.S.A.

\section{José Luís Altmayer Pizzorno}

Projeto Monitoramento de Baleias por Satélite,

Instituto Aqualie, Rua Edgard Werneck, 428/32,

Rio de Janeiro, RJ, 22763-010, Brazil

\section{Phillip J. Clapham}

National Marine Mammal Laboratory,

Alaska Fisheries Science Center, NOAA Fisheries, 7600 Sand Point Way NE,

Seattle, Washington 98115-6349, U.S.A. 
Humpback whales (Megaptera novaeangliae) occur in all major oceans of the world, where most populations typically migrate between high-latitude summer feeding areas and low-latitude wintering grounds (Mackintosh 1942, Clapham and Mead 1999). Historical and contemporary data indicate that a humpback whale population spends the winter breeding season (typically June-November; Martins et al. 2001) in waters over the continental shelf off the eastern coast of South America $\left(5^{\circ}\right.$ $21^{\circ}$ S; Williamson 1975, Zerbini et al. 2004, Andriolo et al. 2006). This population migrates through oceanic waters to summer subantarctic feeding destinations near South Georgia $\left(\sim 54^{\circ} \mathrm{S}, 36^{\circ} \mathrm{W}\right)$ and the South Sandwich Islands $\left(\sim 58^{\circ} \mathrm{S}, 26^{\circ} \mathrm{W}\right)$ in the Scotia Sea (Zerbini et al. 2006).

Humpback whale feeding behavior is highly seasonal, and its occurrence is extremely rare during the period of residency in low-latitude waters, when whales typically fast for extended periods (Mackintosh 1942, Chittleborough 1965). However, occasional winter feeding events have been reported in some populations (Baraff et al. 1991, Gendron and Urbán 1993, Swingle et al. 1993, Stockin and Burgess 2005). Here we report the first documented case of humpback whales feeding on a major wintering ground off Brazil.

The events reported here were opportunistically observed from an oil platform located at $19^{\circ} 35^{\prime} 02^{\prime \prime} \mathrm{S}, 39^{\circ} 14^{\prime} 37^{\prime \prime} \mathrm{W}$, where the water depth was $67 \mathrm{~m}$. On 8 August 2005 , two humpback whales were observed feeding near the platform. Both individuals were estimated visually at approximately $10 \mathrm{~m}$ in length, suggesting they were juveniles. The animals were observed close to the platform for $37 \mathrm{~min}$ (between 1322 and 1359), and the observer started registering their behavior as soon as the animals were observed. During this period, they were observed swimming in a circular fashion and feeding near the surface at least six times (feeding behavior was documented by photographs and video). The whales were targeting schools of unidentified small forage fish, which were seen in the waters surrounding the oil platform. The whales pursued the fish schools, positioned themselves laterally below the surface and then opened their mouths in typical lunge-feeding behavior. Once the prey was ingested, the whales returned to a horizontal position to expel the water out of the mouth. Despite swimming in close proximity, the two individuals were not observed feeding in synchrony.

During these observations, whales were occasionally out of sight; thus, the number of feeding occurrences may have been underestimated. When in sight, surfacing frequency was high, with dive durations shorter than 1 min. Swift kicks of the tail were also seen, but did not always precede the feeding events; such behavior was also recorded in a feeding whale in the West Indies (Baraff et al. 1991), and has been frequently observed as an apparently intentional feeding strategy on feeding grounds in the Gulf of Maine (Weinrich et al. 1992).

Despite the fact that the platform was operational at the time, the whales approached it and stayed in the nearby area for at least $2 \mathrm{~h}$ (according to platform crew members). It is hard to say how frequent this behavior occurs near the platform, due to the fact that generally no specialized observer stays at the platform. 
As here, other previously reported instances of feeding on a breeding ground also involved presumed juveniles (Baraff et al. 1991, Swingle et al. 1993), judged by the size of the individuals seen. However, maturity state cannot be confirmed from these visual observations. Stevick (1999) showed that Northern Hemisphere humpback whales can be mature at lengths of only $11 \mathrm{~m}$. Whether tropical feeding occurs only in younger animals which have less incentive to participate in breeding activities is currently unknown. Juvenile humpback whales, which have thinner blubber layers than adults, may also be less prepared to withstand a prolonged fast where they live off of stored energy reserves, and that their smaller size makes it more likely that sporadic feeding on small prey patches will have a positive effect on their annual energy budget than in larger adults.

The humpback whales observed in this study exhibited the behavior that was similar to that in other documented cases of low-latitude feeding (Baraff et al. 1991, Swingle et al. 1993). Unlike in the Northern Hemisphere, feeding on fish is thought to be rare among Southern Hemisphere humpbacks, whose principal prey is euphausiids (Evans 1987). That austral populations occasionally prey on fish is suggested by our Brazilian observations, together with those of Stockin and Burgess (2005), who recorded opportunistic feeding of an adult humpback whale migrating along the coast of Australia.

We will likely never understand the mechanisms that initiate and inhibit hunger, and that are responsible for this apparently abnormal behavior in the tropics. However, in light of the energetic demands of a winter fast, it is not surprising that humpback whales occasionally utilize abundant prey resources that become available during their long residency in tropical waters.

\section{Literature Cited}

Andriolo, A., C. C. A. Martins, M. H. Engel, J. L. Pizzorno, S. Masrosa, M. E. Morete AND P. G. KINAS. 2006. The first aerial survey to estimate abundance of humpback whale (Megaptera novaeangliae) in the breeding ground off Brazil. The Journal of Cetacean Research and Management 8:307-311.

Baraff, L. S., P. J. Clapham and D. K. MatTila. 1991. Feeding behavior of a humpback whale in low-latitude waters. Marine Mammal Science 7:197-202.

Chittleborough, R. G. 1965. Dynamics of two populations of the humpback whale, Megaptera novaeangliae (Borowski). Australian Journal of Marine and Freshwater Research 16:33-128.

Clapham, P. J., ANd J. G. Mead. 1999. Megaptera novaeangliae. Mammalian Species 604:1-9.

Evans, P. G. H. 1987. The natural history of whales and dolphins. Christopher Helm Ltd., Worcester, U.K.

Gendron, D., AND J. URBan. 1993. Evidence of feeding by humpback whales (Megaptera novaeangliae) in the Baja California breeding ground, Mexico. Marine Mammal Science 9:76-81.

Mackintosh, N. A. 1942. The southern stocks of whalebone whale. Discovery Reports 22:197-300.

Martins, C. C. A., M. E. Morete, M. H. Engel, A. Freitas, E. R. Secchi and P. G. KINAS. 2001. Aspects of habitat use patterns of humpback whales in the Abrolhos Bank, Brazil, breeding ground. Memoirs of the Queensland Museum 47:563570 . 
Stevick, P. T. 1999. Age-length relationships in humpback whales (Megaptera novaeangliae): A comparison of strandings in the western North Atlantic with commercial catches. Marine Mammal Science 15:725-737.

Stockin, K. A., AND E. A. Burgess. 2005. Opportunistic feeding of an adult humpback whale (Megaptera novaeangliae) migrating along the coast of Southeastern Queensland, Australia. Aquatic Mammals 31:120-123.

Swingle, W. M., S. G. Barco, T. D. Pitchford, W A. Mclellan and D. A. Pabst. 1993. Appearance of juvenile humpback whales feeding in the nearshore waters off Virginia. Marine Mammal Science 9:309-315.

WeinRich, M. T., M. R. SChilling AND C. R. Belt. 1992. Evidence for acquisition of a novel feeding behaviour: Lobtailing feeding in humpback whales, Megaptera novaeangliae. Animal Behaviour 44:1059-1072.

Williamson, G. R. 1975. Minke whales off Brazil. Scientific Reports of the Whales Research Institute, Tokyo 27:37-59.

Zerbini, A. N., A. Andriolo, J. M. Da Rocha, P. C. Simões-lopes, S. Siciliano, J. L. Pizzorno, J. M. Waite, D. P. Demaster and G. R. VanBlaricom. 2004. Winter distribution and abundance of humpback whales off Northeastern Brazil. Journal of Cetacean Research and Management 6:101-107.

Zerbini, A. N., A. Andriolo, M. P. Heide-jørgensen, J. L. Pizzorno, Y. Geyer, G. R. Vanblaricon, D. P. Demaster, P. C. Simões-lopes, S. Moreira and C. Bethlem. 2006. Satellite-monitored movements of humpback whales (Megaptera novaeangliae) in the Southwest Atlantic Ocean. Marine Ecology Progress Series 313:295-304.

Received: 25 February 2008

Accepted: 22 July 2008 